\title{
Does Strategic Alliance Matter In Managing Innovation In China?
}

Li (Isabella) Liu, Royal Holloway College, United Kingdom

Sajjad M. Jasimuddin, Kedge Business School, France

David Faulkner, Royal Holloway College, United Kingdom

\begin{abstract}
Innovation is the route to competitive advantage for a firm. In this regard, strategic alliances, particularly international joint venture (IJV), is an effective vehicle for creating innovation capabilities. This paper attempts to explore innovation activities in IJVs between Chinese and Western companies. China is currently largely an OEM country that supplies the whole world with a wide variety of products. However it still lacks a higher level of innovation. The paper reports a qualitative study conducted at two Sino-Western IJVs about how IJVs can help Chinese companies to become innovative. China has easy access to foreign technology, but is weak in its domestic clustering of technology infrastructure. Sino-Western joint ventures are found useful in creating transferable innovation in China. The paper suggests key success factors for creating innovation capabilities through IJV formation.
\end{abstract}

Keywords: Innovation; IJVs; China; Innovative Capabilities; Innovative Network; Intellectual Property; Open Innovation; Strategic Alliances

\section{INTRODUCTION}

Q)

hina's inward foreign investment has developed at a rapid rate during the last 30 years, thereby gaining a path of breathtaking economic growth. For example, in 2004, its GDP reached \$1.64 trillion in absolute dollar terms, making it the sixth largest economy behind the US, Japan, Germany, Britain, and France (Xu et al., 2006). Strategic alliances, which Culpan (2009) defines as a variety of interfirm partnerships between and among firms to gain a competitive advantage, plays a great role for the China's rapid economic growth. The fact is that strategic business alliances have increased in number in today's global business environment (Culpan, 2009). International Joint Ventures (IJVs) have recently become an increasingly important mode of foreign entry into host countries, including China. While the Western company's motivation is generally to gain access to a vast market of 1.3 billion people, and to manufacture at the low labour costs that exist in China, Chinese partners intend to gaining access to Western technology and management as the normal motivation.

China has been the subject of a large amount of media and academic interest particularly over the last ten years, since it has become apparent in the West that China is rapidly becoming a world economic power. In the area of manufacturing it seems to provide a large percentage of the world's traded and manufactured products, most of which appear under well-known Western brand names (Gu, 2005). Although China is currently an Original Equipment Manufacture (OEM) country that supplies the world with a mass of products, it intends to transform itself into a brand name country $(\mathrm{Gu}, 2005)$. The fact that innovation is a powerful enabler, because a firm with greater innovativeness will be more successful in creating value and enhancing competitive advantage. The purpose of this paper is to discuss how IJVs can help Chinese companies to become innovative, by exploring and identifying innovations in two IJVs based in China.

The paper is structured as follows: Section 2 reviews the relevant literature, followed by Section 3 that focuses on methods used to undertake a qualitative research. Various factors related to innovation activities in China are identified in Section 4. Section 5 discusses the interactions of the forces involved that seeks to improve innovation capability in China. The final section provides the concluding remarks with a discussion of limitations, and directions for future research. 


\section{LITERATURE REVIEW}

International Joint Ventures (IJVs) provide great opportunities for partner firms to learn from each other and to gain access to each other's resources and embedded knowledge on various aspects of the JV's operations (Evangelista \& Hau, 2009). Although the great outpouring of academic literature on IJVs and other forms of corporate cooperation belongs to the 1990s, there has been comparatively little literature that analyses the nature of the JVs and charting the path to genuine brand name companies in China, similar to those that developed in the 1960s in Japan and in the 1980s in South Korea. There is, however, a wealth of scholarly research on various aspects of foreign investment in China, for example, learning and knowledge management in alliances (Inkpen \& Currall, 2004), trust, control, and learning in JVs (Currell, 2004), performance in IJVs (Child \& Yan, 2003), trust in the Chinese context (Mollering, 2003), HRM policies used strategically in IJVs (Farley et al., 2004; Warner, 2003), culture of both national and organisation types in IJVs (Pothukuchi et al., 2002), managing JVs (Child et al., 2005) and China's transition as an emerging economy (Child \& Tsai, 2005), knowledge transfer in China (Jasimuddin et al., 2012), and innovation capability in China (Jasimuddin et al., 2014).

Most specifically, the existing literature contributes to the theory of IJVs and innovation. For example, this literature suggests that key success factors for IJVs include trust between the partners, good partner selection, mechanisms of fostering cooperation, a sensitive approach by both partners to each other's culture and corporate behavioural routines. However, the previous research did not address the key issue of how international strategic alliances help Chinese companies to enhance innovation capability that may lead the local firms to evolve from pure low cost manufacturing units into genuine brand name companies comparable to those in South Korea or Japan. This paper intends to partially fill that gap.

There is no universal definition of innovation. Bozeman and Link (1983) attempt a definition thus "Innovation is the creation of something new. An invention becomes an innovation when it is put to use." In this regard, Tidd et al. (2005) argue that there are various types of innovation, which includes:

- $\quad$ Product innovation. Product innovation is perhaps the most common form of innovation and is seen in the development of a product that previously did not exist. OECD (2005) suggests a product innovation as 'the introduction of a good or service that is new or significantly improved with respect to its characteristics or intended uses. Most specifically, product innovation includes significant improvements in technical specifications, components and materials, incorporated software, user friendliness or other functional characteristics; e.g., the iPod, or the development of an existing product in an altogether different way.

- $\quad$ Process innovation. Process innovation involves manufacturing in a new way. OECD (2005) contends that a process innovation is the implementation of a new or significantly improved production or delivery method. This includes significant changes in techniques, equipment and/or software, any system that makes the delivery of the product to the customer easier, such as computer systems, or a new tracking system. The most obvious examples here have been in the automobile industry. Cars were first made one by one in craft-based fashion. Then we had the assembly line, which became more sophisticated by just-in-time manufacturing or inventory control, and then ultimately by the installation of robots for many routine processes. It is to be noted that the 'lean machine' approach becomes popular to replace the assembly line altogether.

The increasing role of IJVs in the 1980s was due to the accelerating pace of technological innovation and the globalization of markets. The very existence of a new JVs gives rise to innovation as the venture established its place in the organizational framework of the partner companies. Thus in investigating this subject, we look for innovation in the partner companies subsequent to the establishment of the JV, and for innovation in the JV itself.

China has traditionally had a very weak innovation research structure, unlike Japan and South Korea which became an established developed nations in the 1960s and 1980s respectively, largely because they were capable of 'playing catch-up' with the Western nations through a strong innovation commitment. China, however, probably due to its Confucian heritage, accorded more social status to the humanities than to science and technology. As a result after the introduction of an open door policy, China becomes the manufacturing hub of the world. China is still dominated by low value added manufacturing with margins of 5\% or less (Gu, 2005). Over 80\% of exported 
manufactured goods from China come from foreign-owned factories or JVs, and the dominant sources of Chinese Foreign Direct Investment (FDI) is the Chinese Diaspora, to be found particularly in Singapore, Taiwan, and Hong Kong.

Unfortunately, as in many planned economies, production facilities and research and development (R\&D) institutes have operated separately, and therefore do not interacted synergistically. Gu (1999) states that the recent Chinese policy reform document entitled "Endogenous growth through harmonious development" recognizes this, by stimulating innovation through bringing companies and R\&D together.

In this regard, Zhao Zhang, former Minister for Industry, noted that separation of R\&D and production was no longer appropriate and set up NTE's (New Technology Enterprises) starting from 1985 (Gu, 1999). More recently under the reform package the Chinese innovation system has developed, which includes the following salient features:

- $\quad$ R\&D institutes are being merged into capital goods industries where innovation is important to competitive success in global markets.

- Inflow of technology is being encouraged through Technology Licensing (TI), Sample Machine Procurement (SMP), Equipment Procurement (PE), Foreign Direct Investment (FDI), and Original Equipment Manufactures (OEMs).

- $\quad$ Interactive relationships between joint venture partners ( $\mathrm{Gu}, 1999)$.

China has easy access to foreign technology, but is weak in its domestic clustering of technology infrastructure. The import of foreign technology is largely embodied in new machinery and other process equipment. China still has poor support for knowledge based growth because of its poor technology infrastructure (Nelson, 2004), Sino-Western JVs are extremely important in creating transferable innovation on Chinese soil. The evolution of a developed nation is generally said to be in the following stages: Manufacturing (Stage 1), R\&D (Stage 2), and Branding (Stage 3). While China is making some progress on R\&D having initially concentrated on manufacturing, the third stage is still largely for the future. In order to achieve a good understanding of how a JV between Chinese and Western companies creates and maintains technological innovative capabilities for Chinese firms, a series of interviews were conducted in the two Sino-Western IJVs based in China.

\section{RESEARCH DESIGN}

There is limited literature on innovation capacity in China. A case study approach was chosen to investigate the role of IJVs in creating innovation capability in China which seems to partially fill the gap in the literature. Moreover, the use of a case study approach allows us to identify variables and their interactions (Eisenhardt \& Graebner, 2007). In order to understand the nature of innovative activities being undertaken in China, this research collected data from primary sources; i.e., interviews and observations. A semi-structured interview schedule was used to facilitate interviews (see Appendix-1).

As shown in Table 1, the two case organizations were approached because they were specially chosen for particular attributes. They create innovative capabilities for Chinese firms through IJV, representing an engineering industry and a service industry in the exploration of the use of the East-West joint venture as a vehicle for increasing the level of innovation in the Chinese economy. The chosen organizations were representative of the IJVs in China in terms of timing (Inkpen, 1995). For this research, the firms that had been formed as a joint venture in China for a period of at least ten years were selected. And both IJVs are among the earliest strategic alliances at the beginning of open door policy. They completed their initial 10 year contacts and have renewed the venture with continual contact.

Sixteen interviewees were purposively selected from two IJVs to "confirm or disconfirm inferences drawn from the others" (Yin, 2003). Interviews of 16 managers were held in factory offices based in Beijing, who described their experiences in innovation activities within their organizational setting. The normal length of an interview was an average of 1.5 hours. Interviews were allowed to be tape-recorded. Interview notes were also taken during interview sessions. One of the three authors of this paper conducted the interviews who was proficient in both English and Chinese. 
The top managers are responsible the innovation activities in the IJVs. The senior managers, such as the strategy manager, marketing manager, finance manager, human resource manager, and the General Manager were selected to conduct interviews. Eight senior managers, each from two JV companies, are interviewed. In order to achieve some triangulation, we sought data and information from annual reports and specific literature on organization's underlying philosophy towards innovation and working practices in addition to the interviews.

Data analysis involved an extensive task of transcription, coding, and analysis, which was conducted manually. To begin with, the interview recordings and transcripts were reviewed. The associated themes were then put together and their common properties were found when referring back to the context in the transcripts.

Table 1: Description of Case Studies

\begin{tabular}{|c|c|c|c|}
\hline IJV Company & Partners & Country of Origin & Business in China (Years) \\
\hline \multirow{2}{*}{$\begin{array}{l}\text { A. Yantain International } \\
\text { Container Terminals } \\
\text { Limited }\end{array}$} & $\begin{array}{l}\text { 1. Hong Kong Hutchinson } \\
\text { Port Holdings (HPH) Group }\end{array}$ & UK then HK & 14 \\
\hline & $\begin{array}{l}\text { 2. Shenzhen Yantian Port } \\
\text { Group }\end{array}$ & China Local Partner & \\
\hline \multirow{2}{*}{$\begin{array}{l}\text { B. Shanghai Fleetguard } \\
\text { Filter Co., Ltd. }\end{array}$} & $\begin{array}{l}\text { 1. Cummins Engine } \\
\text { Company }\end{array}$ & USA & 12 \\
\hline & $\begin{array}{l}\text { 2. DFM (Dong Feng Motor } \\
\text { Corporation) }\end{array}$ & China Local Partner & \\
\hline
\end{tabular}

\subsection{Case 1: Yantian International Container Terminals (YICT) Limited}

Hutchison Port Holdings (HPH) Group is the world's leading port investor, developer, and operator with interests in 15 countries throughout Asia, the Middle East, Africa, Europe, and the US. Today, HPH manages a total of 32 ports together with a number of transportation related service companies. Following China's open door policy, the Chinese economy began to develop strongly, and China felt the need to build its own port. In 1994, HPH and Shenzhen Dongpeng Industry Company Limited (now renamed Shenzhen Yantian Port Group) signed the JV contract establishing Yantian International Container Terminals Limited. The motivation behind the joint venture from HPH's side was to expand its business to mainland China and get a share of a very large market. From Shenzhen Yantian's side, the main aim was to gain the knowledge about managing port construction and operation.

The fact is that a port is regarded as an economic barometer. An enormous export-oriented economy has to depend largely on a strong world-class port. Over ten years of operations, China has its own port which has already become the fourth biggest container port in the world. Every day cargo from cities including Shenzhen, Dongguan, and Huizhou is delivered to the world via Yantian. These "Made in China" products, from colourful toys for children in the USA to the various Christmas gifts in the European markets, are becoming popular all over the world. YICT has consequently become a preferred gateway to exporters in South China for exporting their cargo. YICT is one of the most important and convenient port for exports from China to the USA. Here at YICT, every four hours there is one container vessel heading to the Americas and one to Europe every eight hours. According to statistics from PIERS Global Intelligence Solutions, up to $28.7 \%$ of the total US-bound containers from China were shipped via YICT from August 2005 to July 2006. The fact that YICT is called "Port of Toys," "Port of Shoes," and "Port of Electronic Products."

Operating around the clock, YICT provides port services to numerous well-known shipping lines including the world's top 20. It is spearheaded by the top 20 shipping lines. About 40 liner companies call at YICT. Several international logistics operators and exporters have set up warehouses and offices near the port - to take advantage of YICT's efficient services. As a major port in Shenzhen for ocean-going ship, YICT has made substantial contributions to Shenzhen confirming its ranking as the world's fourth largest container port. Presently, YICT has 12 deep-water container berths and over 80 regular shipping services covering the world, providing the local importers and exporters with efficient terminal services.

\subsection{Case 2: Shanghai Fleetguard Filter Co. Limited}

Pudong stands at the head of Chang Jiang River and beside the East Sea to the East of Shanghai. The open door policy has been well implemented in this enterprising region. Shanghai Fleetguard Filter Co Ltd is a SinoCopyright by author(s); CC-BY 
American joint venture between Cummins Engine Company and Dong Feng Motor (DFM) Corporation. Cummins motivation for the JV was to work with DFM Corporation to gain knowledge of the Chinese motor industry, and access to the large Chinese market. From DFM's viewpoint they intend to gain enough capital investment to support Chinese car manufacturing through modern technology and management methods.

Shanghai Fleetguard Filter Co., Ltd has been formed between Fleetguard Inc. and Shanghai Shenlong Auto Accessory Co. Ltd (SSAA). Fleetguard Inc, a wholly owned company of Cummins Engine Company, is a cross continental company with plants in US, Britain, France, Mexico, Belgium, India, and Korea. The company's headquarters is in Nashville, Tennessee. It is the largest filter maker in the world to serve the market of automobile, civil engineering, generator sets, and marines. The company has a world-wide reputation for high quality filters and premier service.

Fleetguard (Fleetguard Inc.), founded in 1958, is a subsidiary of Cummins Engine Company. As a technology leader in manufacturing and designing of diesel engine in the world, Fleetguard Inc. has set up 23 plants in 9 countries, 15 distribution centres as well as three JVs around the world. There are more than 160 OEM plants, located around the world.

As a partner of Shanghai Fleetguard Co, Ltd, Shanghai Shenlong Auto Accessory Company has been formed between DFM Corporation, Gao Hang Hydraulic Parts Plant, and Dong Gou Industry Corporation. Dong Feng Motor Corporation has major equity in SSAA. DFM Corporation founded in 1969, which is the leading manufacturer of cars and trucks in China. Based in Hubei, the company's business extends nationwide and is developing internationally, integrating manufacturing, scientific research, and trading into a very large scale enterprise. It owns 32 specialized plants, 22 fully invested or share controlled companies, working with international technology leaders to bring world-class products to China.

China's automobile industry is still several decades behind world levels. Cummins has an established reputation for delivering high-quality, technologically advanced products. Cummins' continuous work with the customers to develop new products to improve the performance of their vehicles, equipment or systems at competitive cost levels is very high. Cummins are a leader in developing technologies to reduce diesel engine emissions, a key concern of the customers and regulators around the world.

Shanghai Fleetguard Filter Co Ltd (the JV Company) was established by DFM and Fleetguard the subsidiary of American Cummins Engine in 1994 with a total investment of 15 million US dollars. Shanghai Fleetguard entered a new chapter in its history in 2007. It is now growing as a world class company with advanced equipment and management, with annual production capacity of 4 million spin-offs and 1.1 million air filters, responsive system to market demand. It has established a complete distribution network to serve DFM, Cummins market, and other customers in domestic and international markets.

\section{RESULTS}

Innovation plays a crucial function in globalized competition. Innovation is the main resource of national competitive strength. Scientific knowledge and technology are regarded as primary productive factors for innovation. China tries to catch up with the Western advanced countries, but the lack of capital investment and educated researchers cause slow progress in terms of its innovation. As noted earlier, China has reformed and implemented an open door policy for 30 years. Chinese economic development becomes the focus of the world attention.

But compared with the developing Western countries, China falls behind them in patents and patents commercialization. Nowadays the quality and quantity of patents are used to measure the national scientific technology level in the world. Likewise, commercialization of patents is used to measure national international competition force and economic development. According to the World Economic Forum (The Global Competitiveness Report 2008-2009), the ranking of China in Growth Competitiveness Index (GCI) is ranked 30 out of total 102 countries (see Table 2). 
Table 2: The Global Competitiveness Index 2008-2009

\begin{tabular}{|c|c|c|c|c|c|c|c|c|}
\hline \multirow{3}{*}{ Country/Economy } & \multirow{2}{*}{\multicolumn{2}{|c|}{ OVERALL INDEX }} & \multicolumn{6}{|c|}{ SUBINDEXES } \\
\hline & & & \multicolumn{2}{|c|}{ Basic Requirements } & \multicolumn{2}{|c|}{ Efficiency Enhancers } & \multicolumn{2}{|c|}{ Innovation Factors } \\
\hline & Rank & Score & Rank & Score & Rank & Score & Rank & Score \\
\hline United States & 1 & 5.74 & 22 & 5.50 & 1 & 5.81 & 1 & 5.80 \\
\hline Singapore & 5 & 5.53 & 3 & 6.14 & 2 & 5.52 & 11 & 5.16 \\
\hline Japan & 9 & 5.38 & 26 & 5.36 & 12 & 5.22 & 3 & 5.65 \\
\hline Hong Kong SAR & 11 & 5.33 & 5 & 6.05 & 6 & 5.43 & 21 & 4.69 \\
\hline United Kingdom & 12 & 5.30 & 24 & 5.46 & 4 & 5.45 & 17 & 4.93 \\
\hline Korea, Rep. & 13 & 5.28 & 16 & 5.71 & 15 & 5.15 & 10 & 5.20 \\
\hline Taiwan, China & 17 & 5.22 & 20 & 5.53 & 18 & 5.06 & 8 & 5.26 \\
\hline China & 30 & 4.70 & 42 & 5.01 & 40 & 4.41 & 32 & 4.18 \\
\hline India & 50 & 4.33 & 80 & 4.23 & 33 & 4.49 & 27 & 4.29 \\
\hline Russian Federation & 51 & 4.31 & 56 & 4.54 & 50 & 4.29 & 73 & 3.56 \\
\hline Brazil & 64 & 4.13 & 96 & 3.98 & 51 & 4.28 & 42 & 4.04 \\
\hline
\end{tabular}

Source: Porter, Michael E., Schwab, K., \& Sala-i-Martin, X. The Global Competitiveness Report 2008-2009 by World Economic Forum, (Paperback - Feb 19, 2009)

\subsection{The Role of Networks in Innovation}

Several authors, most notably Nambism (2002) and Perks and Jeffery (2006), describe that nowadays nearly all industries are facing the challenges of globalization. Value chains across national boundaries as various activities from idea generation to manufacturing and marketing are conduced in different countries. Within the value chain, innovation activities are globally distributed. Criscuolo et al. (2005) state that innovation and R\&D activities are becoming internationally organized. According to Manolopoulos et al. (2005), multinational companies (MNCs) use innovation to increase their competitive advantages. Innovation can be transmitted inside the firm boundaries from country to country. Gupta and Govindarajan (2000) describe that the internationally connected company can learn from the local environment, which increases more innovations. Similarly, Martin and Salomon (2003) state that innovation and internationalization are increasingly intertwined: innovative knowledge assets are required for successful international growth, and, on the other hand, new value and innovations can be created more through internationalization as it supports creating and utilizing such assets widely.

Although innovation activities in international settings can certainly happen within MNC, they rarely are carried out completely within a single organization (Cantwell, 1995). Networks can help to access and exploit both internal and external resources to create more innovation. Several scholars (e.g., Johanson \& Mattsson, 1988), argue that network can bring a source of global competitive advantage for a company.

Over the past ten years inter-organizational networks are becoming more important. Networks can build up innovative capabilities, including collecting different kinds of ideas, accessing resources easily, and enhancing the transfer of knowledge. When a firm cannot achieve the goals by itself, strategic alliances could help enhance innovation so that all the firms can accomplish the goal together. The investments in mutual learning and the diverse collaborations are associated with increased patenting, which is an important outcome of the innovation process.

According to Powell and Grodal (2005), the members of a network that effectively share their information and skills depend on the nature of knowledge, conceptualized in term of tacitness or explicitness. It is easier for the networks rooted in a division of innovative labour to transfer tacit knowledge in the form of finished inputs. However, the networks involved in the co-creation of novel ideas may succeed. Or the networks may fail due to the capability to convey and transfer ideas in firms, as the ideas are not easily codified.

\subsubsection{Network Dynamics}

Powell et al. (1996) point out that external collaboration can help firms to develop technological ideas fast. They find out that the firms that develop experience at managing collaborative R\&D relationships will become the centrally positioned firms. The more the firm has experiences and collaboration with partners, the greater the innovation the firm can expect in the industry. The strong relationships with diverse partners will help firms stay in a leadership position in the industry (Powell \& Grodal, 2005). 
Innovation and networks establish a positive cycle. External networks help to create the innovation. At the same time, the more the alliance involved in networks, the greater the innovation outputs. Both of these two factors support the firm's growth and enhance further innovation. Several authors, most notably Ahuja (2000) and Stuart (2000), argue that the firms with many prior patents are more likely to form alliances than firms lacking patents, suggesting that collaborative ties are very vital in the process of innovation and growth. In this regard, one strategy manager working in Shanghai Fleetguard Filter Co. Limited remarked:

"Becoming part of an innovative network in our industry helps us to increase innovative capabilities. We are the IJV Child of our parent companies. Our parent is a big company. It is a big innovation network, organization network, sales network and marketing network. We become a part of innovative network of both parents. Our western parent company is a worldwide corporation and has advanced technology in our industry. We can be supported by their worldwide innovative resources."

The question remains as to how innovation is impacted by the network form of organization. Dhanaral and Parkhe (2006) explore the process issue in network management which implicates network theory, strategy, knowledge management, alliances, and international business. They develop the framework for orchestration in innovation networks, identifying three processes: knowledge mobility, innovation appropriability, and network stability. The orchestration framework has some implications for managers in firms that have large networks. For example a Director of Marketing Department based in Yantian International Container Terminals Limited observed:

"We have formal and informal ties within our parent companies. In formal collaborations, when we can not achieve the goals by ourselves, the collaborations within parent group could help worldwide, so that we and other firms within parent group can accomplish the goal together. We also have informal ties with other firms. The formal ties are strongly supported by informal connections."

\subsection{Innovation and Developing Intellectual Property Rights}

The relationship between innovation and patents are always focused both in the field of innovation management. Patents can protect inventions (judged as sufficiently novel), trade secrets, copyrights, trademarks, design right, and database right to use for their own to make more profit. Until recently, intellectual property right (IPRs) has the central position in economic policy, national competitiveness and social welfare (Granstrand, 2005).

'Trade related aspects of IPRs' (TRIPS) are the latest links between trade and intellectual property protection. US-originated pro-patents or pro-IP era appeared since the 1980s. In the 21st century, knowledge (and information), innovation, and intellectual capital become the strongest base of the new capitalist economy. Although its record is improving fast, China only registered 3,900 patents on the latest figures compared with more than 26,000 for Japan and nearly 50,000 for the US in 2007 (World Intellectual Property Organisation 2007). In this regard, a manager of Yantian International Container Terminals Ltd pointed out:

"In Chinese enterprises, intellectual property rights are few, the level of patents technology is not high, and the internationalization degree of patents is low. The major factors that restrict the development of intellectual property rights in Chinese enterprises are institution, policy, society and internationalization. We must establish institution to help develop intellectual property rights; carry out the policy and law to encourage and support the enterprises to develop them, and create a social environment which is beneficial for the enterprise to develop intellectual property rights."

On the other hand, patents prevent other organizations in the society from sharing the innovation. Ordover and Janusz (1991) state that patents have both dynamic efficiencies and static inefficiencies. When patents protect the innovator, it increases the innovator's revenue and profit. The innovators can carry on the long term and big scale R\&D. This is patents dynamic efficiencies. The patents enable the innovator to monopolize the market, the innovator has competitive advantage, and other organizations can not use their innovation freely. An operation manager working in Shanghai Fleetguard Filter Co. Ltd noted:

"China has recently legislated to protect intellectual property; although this is required by the WTO.... China has established protection system very late, and China has a weak consciousness to protect intellectual property. 
Parallel to this, a Director of Strategy department based in Yantian International Container Terminals Ltd explained:

"Intellectual Property is the way to help create innovation. Every company which intends to invent new technology or new product must spend the assets, resources, time. The patents can protect the innovation. This is a sense of security."

\title{
4.3 Open Innovation System
}

Open Innovation is seen as important to companies to avoid too much inward looking research. It helps to create more innovation for Chinese firms. According to Chesborough (2004), the open innovation paradigm can be described as internal R\&D activities which lead to internally developed products that are then distributed by the firm. In other words, open innovation is the use of inflows and outflows of knowledge to speed internal innovation, and expand the markets for external use of innovation. A firm should use both external and internal ideas and internal and external paths to market in order to advance their technology.

The Open Innovation paradigm treats $R \& D$ as an open system through which a company can bring valuable ideas to the company. The valuable ideas can eventually be translated into new product or process which goes to market. Taking part in an open innovation system in its industry helps to create more innovation. A Director of HRM Department working in Yantian International Container Terminals Ltd reflected this view:

"To take part in open innovation system in our industry helps us to create more innovation. I participate in an engineering conference for sharing innovation results and innovative practice in America. Innovative practice is all about learning what the companies are doing, and copying what they are doing. Based on external new technology, we can improve our quality according to our company's capabilities. We share external new information and external new technology. We take part in open innovation system to share the innovative practice in the whole industry, including conference, meeting, training, ......., participate in training run by other companies, and learn from other companies. We participate in conferences about sharing innovation. We show other companies [our] slides, PowerPoint presentation about what we are doing in what way. This is the way we communicate." observed:

Resonating with this, Director of Maintenance Department based in Shanghai Fleetguard Filter Co. Ltd

\begin{abstract}
"We join the engineering society. And we participate in the Institution of Engineering workshops. When we want to introduce new innovative products, we write a paper and sent it to our society. The institution publishes the paper, so other companies and customers will know our new process or product. Or the institution invites us to deliver a seminar. In the seminar, we list the information on new products."
\end{abstract}

\section{DISCUSSION}

As mentioned previously, Yantian International Container Terminals (YICT) is one of the fastest growing container ports in the world. The rapid economic development of the region has created a surge in container traffic. Manufactured goods are shipped worldwide, reaching customers in Europe, the US, and Australia. Thus over the period of its existence and the development of Yantian has been responsible for many powerful process innovations in and around its base city of Shenzhen, which have contributed in a major way to that city's dramatic development. In addition Western partner HPH's has substantially expanded its business to mainland China, and achieved a good share of a very large market. From Shenzhen Yantian's side the main aim was to gain the management knowledge for port construction and operation. This has clearly done very successfully. The JV has therefore been very successful from the viewpoint of both partners. Similarly, Cummins' motivation for the JV was to work with Dong Feng Motor Corporation to gain knowledge of the Chinese automobile industry, and to gain access to the large Chinese market. From DFM's viewpoint they wish to gain enough capital investment to support Chinese car manufacturing through modern technology and management methods. Both the partners have achieved their goals.

It is interesting to observe that both IJV companies studied manifest each of the key success factors, which confirm others' work. It is found that both the case companies have developed a range of innovations, and have 
greatly enhanced the innovative capabilities for their partners. The study reveals three key success factors for creating innovative capabilities, which are as follows.

- $\quad$ becoming part of an innovative network in its industry;

- $\quad$ developing intellectual property (IP) record especially in patents; and

- $\quad$ introducing a philosophy of open innovation.

Becoming part of an innovative network in its industry, particularly a dense networks of strategic alliances especially those with the West, helps to create innovative capabilities for the IJVs. A developed intellectual property (IP) record especially in patents also helps to create innovative capabilities for the IJVs. Currently China is poor in protecting its innovation. It is argued that a strong patent record is evidenced of high R\&D success (Granstrand, 2005). Similarly, adoption of open innovation helps to create innovative capabilities for IJVs, in which innovations are capable of being easily accessed by companies other than the originator.

The fact that there is a linkage between the networking and intellectual property management, and again between networking and open innovation in order to fostering greater innovation. Networks help to access and exploit both internal and external resources to build up innovative capabilities so as to create more innovation (Powell \& Grodal, 2005). The investments in mutual learning and the diverse collaborations are associated with increased patenting, which is an important outcome of the innovation process. Patents can protect the IJVs to use their innovation on their own to make more profit. However, inter-organizational networks are becoming more important for innovation. The IJVs, to some extent, operate the open system. This contrasts with the closed innovation system in which companies protect their innovations. It is to be noted that when a firm fails to achieve its economic goal (e.g., innovation) by itself, strategic alliance with a partner can help so that all the firms can accomplish the goal together. Open innovation helps that the company can bring valuable ideas both from inside and outside which eventually go to market. Similarly, taking part in an open innovation system in its industry enhances more innovation (Chesborough, 2004).

\section{CONCLUSION}

The paper reports a qualitative study conducted at two Sino-Western IJVs in China about innovation capabilities. Although China has easy access to foreign technology, it is still weak in its domestic clustering of technology infrastructure. The import of foreign technology is largely embodied in new machinery and other process equipment. Thus China still has poor support for knowledge based growth because of its poor technology infrastructure (Nelson, 2004). Sino-Western joint ventures are playing an important role in creating innovation in China. In the two cases, substantial innovation has been created as a result of IJVs with Western companies. This paper identifies the success factors for creating innovative capabilities for Chinese firms through IJVs. The paper suggests that Chinese firms need to develop their innovative capabilities through strategic alliances. It is revealed from the study that both the case organizations have developed a range of innovations, and have greatly enhanced the innovative capabilities for their partners. It is also interesting to note that both IJVs manifest each of these three success factors. If Chinese firms are able to score highly on these three key success factors, they could develop strong innovative capabilities.

The findings of the study could not be generalized because the research was based on the two case organizations drawn from two different sectors. The implications of this study should be evaluated in light of the limitations. Although the paper provides some insights into innovative capabilities in Sino-Western IJVs based in China, a more comprehensive task still awaits for further research. Clearly, future study should undertake an empirical quantitative examination in order to test these three key success factors so as to establish their validity in other emerging countries. Although the study is based on the cross-sectional data, future research can be conducted using longitudinal data to investigate the changes in the dynamic features of innovation. Since the sample size is small, future work can expand their samples to increase the validity. Future research could triangulate in-depth qualitative case studies and quantitative research so as to provide further robust results. Finally, since the samples were drawn only from Western MNCs based in a single country, the results are limited to Western MNCs in China. The study results may not be generalizable to other settings. To overcome this limitation, the study could be expanded in other emerging economies to develop a robust framework of innovation capability. 


\section{ACKNOWLEDGEMENTS}

This research was supported by a grant from the Sino-British Foundation Trust. We would like to thank the SinoBritish Foundation Trust particularly Mrs. Anne Elizabeth Ely, the Chairman of the Trust.

\section{AUTHOR INFORMATION}

Li (Isabella) Liu is a Doctoral Researcher of Strategy Management at Royal Holloway, University of London. She researches into conditions for success in International Strategic Alliances. She also researches into how international joint ventures can help to create innovative capabilities for Chinese firms. Her specialist research area is strategy, in particular International Cooperative Strategy, on which subject she has written and edited a number of papers including the joint papers and books with Professor David Faulkner. Her research fields are cooperative strategy, international strategy, mergers and acquisitions, corporate and competitive strategy, sustainability and corporate responsibility innovation.

Sajjad M. Jasimuddin is an Associate Professor at Kedge Business School, France. He holds his MPhil in International Business from the Judge Business School, University of Cambridge, and $\mathrm{PhD}$ in Strategic Knowledge Management from the School of Management, University of Southampton. His articles were published, among others, in European Management Journal, International Journal of Organizational Analysis, Management Decision, Information Systems Journal, Journal of Operation Research Society, Information Systems Management, Industrial Management \& Data System, International Journal of Information Management, Global Business \& Organizational Excellence, Knowledge and Process Management, Journal of Knowledge Management, International Journal of Technology and Human Interaction, Journal of Business \& Industrial Marketing, Management Research News, Business Strategy Series, Journal of Information \& Knowledge Management, Knowledge Management Research \& Practice, International Journal of E-Business Research, Knowledge Management Review, The Encyclopaedia of Knowledge Management, Advances in Doctoral Research in Management, Asian Affairs, Journal of Management, Journal of Air Transport Management, and Journal of Internet Banking and Commerce. His current research interests are in the areas of international business, strategic management, knowledge management, and information systems. E-mail: sajjad.jasimuddin@kedgebs.com (Corresponding author)

Professor David Faulkner is an Oxford educated economist by background, who has spent much of his early career as a strategic management consultant with McKinsey and Co and Arthur D. Little. He is currently Emeritus Professor of strategy at Royal Holloway, University of London and Director of the MBA and MSc in International management. He is also Visiting Professor at the Open University. On moving into academic life in 1989, he became a lecturer in the Strategy Group in the Cranfield School of Management, and gained a Doctorate from Oxford University (D Phil), researching into conditions for success in International Strategic Alliances. He is a former Deputy Director (Undergraduate Courses) and Deputy Director (MBA) of the Said Business School, Oxford University. He still teaches at Oxford University at Said Business School and Exeter College. His specialist research area is strategy in particular International Cooperative Strategy and Mergers and Acquisitions on which subjects he has written and edited a number of books including: The Oxford Handbook of Strategic (OUP) and The Oxford Handbook of Mergers \& Acquisitions (OUP). His research fields are cooperative strategy, international strategy, mergers and acquisitions, corporate and competitive strategy, sustainability and corporate responsibility.

\section{REFERENCES}

1. Ahuja, G. (2000). The duality of collaboration: Inducements and opportunities in the formation of interfirm linkages. Strategic Management Journal, 21, 17-43.

2. Bozeman, B., \& Link, A. N. (1983) Investments in technology: Corporate strategies and public policy alternatives. New York: Praeger.

3. Chesborough, H. (2004). Managing open innovation: Chess and poker. Research \& Technology Management, 47, 13-16.

4. Child, J., \& Yan, Y. (2003). Predicting the performance of international joint ventures. Journal of Management Studies.

5. Child J, Faulkner, D. O., \& Tallman, S. (2005). Cooperative strategy: Managing Alliances, networks and joint ventures. Oxford University Press. 
6. Child, J., \& Tsai, T. (2005). The dynamic between firms: Environmental strategies and institutional constraints in emerging economies. Journal of Management Studies, 42, 95-125.

7. Criscuolo, P., Narula, R., \& Verspagen, B. (2005). Role of home and host country innovation systems in R\&D internationalization: A patent citation analysis. Economics of Innovation and New Technology, 15, 417-433.

8. Culpan, R. (2009). A fresh look at strategic alliances: research issues and future directions. International Journal of Strategic Business Alliances, 1, 4-23.

9. Evangelista, F., \& Hau, L. N. (2009). Organizational context and knowledge acquisition in IJVs: An empirical study. Journal of World Business, 44, 63-73.

10. Eisenhardt, K. M., \& Graebner, M. E. (2007). Theory building from case studies: Opportunities and challenges. Academy of Management Journal, 50(1), 25-32.

11. Farley, J. U., Hoening, S., \& Yang, J .Z. (2004). Key factors influencing HRM practices of overseas subsidiaries in China's transition economy. International Journal of Human Resource Management, 15, 688-704.

12. Granstrand, O. (2005). Innovation and intellectual property rights. The Oxford handbook of innovation. Oxford University Press, New York.

13. Gu, G. Z. (2005). China's competitiveness in a strong-Yuan world, financial sense university. Shenzhen, China.

14. Gu S. (1999). China's industrial technology: Market reform and organizational change. Routledge.

15. Gupta, A. K., \& Govindarajan, V. (2000) Knowledge flows and the structure of control within multinational corporations. Strategic Management Journal, 21, 473-496.

16. Inkpen, A. C., \& Currall, S. C. (2004). The coevolution of trust, control and learning in joint ventures. Organization Science, 15, 586-599.

17. Jasimuddin, S. M., Faulkner, D., \& Liu, L. (2014). How China enhances innovation capability: Perception of IJVs Executives. Global Business and Organizational Excellence, 33(5).

18. Jasimuddin, S. M., Li, J., \& Perdikis, N. (2012). The relationships of knowledge recipients on knowledge transfer at Japanese MNCs based in China. Current Topics in Management, 16, 107-122.

19. Johanson, J., \& Mattsson, L.-G. (1988). Internationalisation in industrial systems - a network approach. In N. Hoodand \& J.-E. Vahlne (eds.), Strategies in global competition (pp. 287-314). London: Croom Helm.

20. Manolopoulos, D., Papanasrassiou, M., \& Pearce, R. (2005). Technology sourcing in multinational enterprises and the roles of subsidiaries: An empirical investigation. International Business Review, 14, 249-267.

21. Martin, X., \& Salomon, R. (2003). Knowledge transfer capacity and its implications for the theory of the multinational corporation. Journal of International Business Studies, 34, 356-373.

22. Mollering, G. (2003). Trust: social science theories and their application to organizations. (Unpublished Ph.D. Thesis). Judge Institute of Management, University of Cambridge.

23. Nelson R. R. (2004). The market economy and the scientific commons. Research Policy, 33, $455-471$.

24. Ordover, A., \& Janusz, A. (1991). Patents system for both diffusion and exclusion. The Journal of Economic Perspective, 5, 43-60.

25. OECD (2005). Oslo manual: Guidelines for collecting and interpreting innovation data. OECD Publishing.

26. Perks, H., \& Jeffery, R. (2006). Global network configuration for innovation: A study of international fibre innovation. $R \& D$ Management, 36, 67-83.

27. Porter, M. E., Schwab, K., \& Sala-i-Martin, X. (2009, Feb 19). The Global Competitiveness Report 20082009. World Economic Forum.

28. Pothukuchi, V., Damanpour, F., Choi, J., Chen, C. C., \& Park, S. H. (2002). National and organizational culture differences and international joint venture performance. Journal of International Business Studies, $33,243-65$.

29. Powell, W. W., \& Grodal, S. (2005) Networks of innovators. The Oxford Handbook of Innovation, $57-85$.

30. Powell, W. W., Koput, K. W, \& Smith-Doerr, L. (1996). Interorganizational collaboration and the locus of innovation: Networks of learning in biotechnology. Administrative Science Quarterly, 41, 116-45.

31. Stuart, T. E. (2000). Interorganizational alliances and the performance of firms: A study of growth and innovation rates in a high-technology industry. Strategic Management Journal, 21, 791-811.

32. Tidd, J., Bessant, J., \& Pavitt, K. (2005). Managing innovation: Integrating technological market and organizational change. NY: Wiley. 
33. Warner, M. (2003). China's HRM revisited: A step-wise path to convergence? Asia Pacific Business Review, 9, 15-31.

34. Xu, D., Pan, Y., Wu, C., \& Yim, B. (2006). Performance of domestic and foreign-invested enterprises in China. Journal of World Business, 41, 261-274. 


\section{Appendix 1: Interview Protocol}

(i) the major activities of the firm

(ii) the nature and characteristics of innovative activities

(iii) motivations of foreign and local partners to form of joint venture

(iv) the relationship between foreign and local partners

(v) resource allocation mechanisms

(vi) the forces involved in innovative activities

(vii) the Chinese government's motivation associated influence to enhance innovation capability

(viii) the role of Chinese universities and research institutes to research collaboration with IJVs

(ix) the network among IJVs, research institutes, and government to have joint collaboration for innovation

(x) both open and closed innovation systems help to enhance innovation capabilities 
NOTES 